\title{
PHENO- AND GENOTYPIC CHARACTERIZATION OF LISTERIA MONOCYTOGENES CLINICAL ISOLATES FROM THE SOUTHWESTERN REGION OF THE STATE OF SÃO PAULO, BRAZIL
}

\author{
Eneida Gonçalves Lemes-Marques ${ }^{1 *}$; Cristina Durante $\mathrm{Cruz}^{2}$; Maria Teresa Destroº \\ ${ }^{1}$ Instituto Adolfo Lutz, Laboratório Regional de Campinas, Campinas, SP, Brasil; ${ }^{2}$ Faculdade de Ciências Farmacêuticas, \\ Universidade de São Paulo, São Paulo, SP, Brasil
}

Submitted: August 31, 2006; Returned to authors for corrections: January 11, 2007; Approved: March 15, 2007.

\begin{abstract}
Considering the lack of information available in Brazil concerning listeriosis, the present study aimed to analyze phenotypic and genotypically Listeria monocytogenes clinical isolates from the Southwestern region of the State of São Paulo, Brazil. From January 1995 to May 2005, thirteen isolates of L. monocytogenes from twelve patients with listeriosis were sent to the Adolfo Lutz Institute (Campinas Regional Laboratory, São Paulo, Brazil). The antimicrobial susceptibility of the isolates was evaluated by the microdilution broth method for ampicillin, gentamicin, trimethoprim, sulfamethoxazole and vancomycin. They were also serotyped (Denka Seiken, Japan), and sub-typed by PFGE employing ApaI and AscI and the American CDC protocol. None of the isolates showed resistance to the antibiotics tested; however, seven of them presented increased values for sulfamethoxazole MICs. Ten isolates belonged to serotype $4 \mathrm{~b}$, two to serotype $1 / 2 \mathrm{a}$ and only one to serotype 1/2b. After digestion with ApaI and AscI, the strains were distributed in 3 different groups according to their profile. It was observed that the spatial or temporally unrelated strains exhibited similar PFGE profiles, indicating a possible clonal relationship among them.
\end{abstract}

Key words: Listeria monocytogenes; serotypes; antibiotic resistance; genotypic characterization; listeriosis

\section{INTRODUCTION}

Listeria monocytogenes is a Gram-positive, nonsporeforming rod and a ubiquitous pathogen in the environment, which grows at temperatures between 1 and $45^{\circ} \mathrm{C}$. It causes listeriosis, an invasive disease with the highest casefatality rate among foodborne illnesses (20 to 30\%) that most frequently affects pregnant women, newborn infants, children, and adults with weakened immune systems. During pregnancy, the infection of the mother may be asymptomatic or characterized by a flu-like illness with fever, myalgia or headache. It may, however, have more severe consequences for the infant, including spontaneous abortion, fetal death, stillbirth, severe neonatal septicemia, and meningitis. In non-pregnant adults, $L$. monocytogenes has a particular tropism for the central nervous system. Gastroenteritis symptoms (vomiting and diarrhea) are observed in some cases, during the week previous to disease diagnosis $(9,25)$. While very rarely mentioned in the literature until recently, few cases of listeriosis have been reported in previously healthy persons and such cases were attributed to exposure to high infective doses, as well as outbreaks of benign febrile gastroenteritis $(2,8,28)$.

Even though $L$. monocytogenes is a potentially dangerous pathogen, in Brazil there is a lack of information available in relation to listeriosis $(3,4,10,12,14,16,17,19)$, antimicrobial resistance of clinical strains $(13,21)$, and their phenotypic and genotypic characterization (22). Therefore, a more accurate study of such infection is necessary in our country.

In general, strains of $L$. monocytogenes are susceptible to a wide range of antibiotics, except for cephalosporins, fluoroquinolones and fosfomycin. The therapy of choice is a combination of ampicillin and an aminoglycoside, usually

*Corresponding Author. Mailing address: Instituto Adolfo Lutz - Rua São Carlos, 720 - Vila Industrial - 13035-420 - Campinas, SP, Brasil. Tel.: (19) 3272-7977 ou (19) 3273-1698. E-mail: eglmarques@ial.sp.gov.br 
gentamicin. In cases when a beta-lactam antibiotic treatment is unfeasible, a second-choice therapy involves the use of an association of trimethoprim and a sulfonamide (such as in cotrimoxazole), erythromycin, or vancomycin $(6,23)$.

Although human listeriosis may be caused by all thirteen serotypes of Listeria monocytogenes (1/2a, 1/2b, 1/2c, 3a, 3b, $3 \mathrm{c}, 4 \mathrm{a}, 4 \mathrm{ab}, 4 \mathrm{~b}, 4 \mathrm{c}, 4 \mathrm{~d}, 4 \mathrm{e}, 7)$, most of the cases are caused by serotypes $1 / 2 \mathrm{a}, 1 / 2 \mathrm{~b}$, and $4 \mathrm{~b}$ (1). In Brazil, serotypes $4 \mathrm{~b}, 1 / 2 \mathrm{a}$, $4 a b, 1 / 2 b, 4 a, 1 / 2 c$ and $3 a$ have been related as the cause of clinical disease (15) with $4 \mathrm{~b}$ and $1 / 2 \mathrm{a}$ being the most prevalent serotypes.

Traditional epidemiological surveillance alone may not detect many common source outbreaks, particularly if a limited number of cases occur over a wide geographic area, due to the unique characteristics of human foodborne listeriosis. Molecular subtyping methods are tools that allow detecting outbreaks and identifying their common source. Among them, pulsedfield gel electrophoresis (PFGE) provides sensitive subtype discrimination and is often considered the gold standard subtyping method for L. monocytogenes (26).

Considering the lack of information available in Brazil concerning listeriosis, the aim of this study was to analyze phenotypic and genotypically the L. monocytogenes clinical isolates from the southwestern region of the State of São Paulo, Brazil.

\section{MATERIALS AND METHODS}

\section{Isolates}

From January 1995 to May 2005, 13 isolates from clinical materials (seven from cerebrospinal fluid, five from blood and one from a liquid collected from an aorta prosthesis) of 12 patients (11 adults and one newborn) were identified as $L$. monocytogenes at the Campinas Regional Laboratory of the Adolfo Lutz Institute (a public health laboratory). The isolates were from six different cities in the Southwestern region of the State of São Paulo, covered by that regional laboratory. The strains were identified in accordance with Rocourt et al. (24). Hemolytic and lecithinase activities were evaluated according to Lemes-Marques and Yano (18).

\section{Antimicrobial susceptibility test}

Antimicrobial susceptibility test was carried out using the microdilution broth method, according to the National Committee for Clinical Laboratory Standards - NCCLS, M7-A6 (20) guidelines, using ampicillin, gentamicin, trimethoprim, sulfamethoxazole and vancomycin. The susceptibility breakpoint used for ampicillin was that in accordance with that of the Clinical and Laboratory Standards Institute - CLSI/NCCLS, M100-S15 (7). All other antimicrobial agents tested had no standardized breakpoints for Listeria spp., so those established for Staphylococcus spp. were used instead (7).

\section{Serotyping}

Serotyping was performed according to the scheme of Seeliger and Höhne (27), using commercial Listeria antisera (Denka Seiken, Tokyo, Japan) in accordance with manufacturer's instructions.

\section{PFGEAnalysis}

Pulsed-field gel electrophoresis was performed according to the Pulsenet-standardized protocol (11), using the enzymes ApaI and AscI. Fragment patterns were analyzed according to Tenover et al. (30). The profile similarities, based on band positions, were derived from the Dice correlation coefficient and clustered by the unweighted pair group method using arithmetic averages - UPGMA (29). A dendrogram was developed using the NTSYSpc 2.0 (Exeter Software, USA).

\section{RESULTS}

\section{Antimicrobial susceptibility test}

No strain was resistant to ampicillin, gentamicin, trimethoprim and vancomycin (Table 1). Strains 5958/04 and 6280/04, isolated from different sources of infection of the same patient, were resistant to sulfamethoxazole (MIC, $128 \mu \mathrm{g} / \mathrm{mL}$ ); and other five strains (17898/98, 4231/00, 22057/01, 30464/01, 544/03) showed reduced susceptibility to this drug (MIC, 16-32 $\mu \mathrm{g} / \mathrm{mL})$.

\section{PFGEAnalysis}

The analysis of macrorestriction patterns obtained by PFGE and the combination of the results obtained with both restriction enzymes, ApaI (Fig. 1) and AscI (Fig. 2), allowed the distribution of the 13 strains in 3 clusters: I, II and III, as shown in Fig. 3.

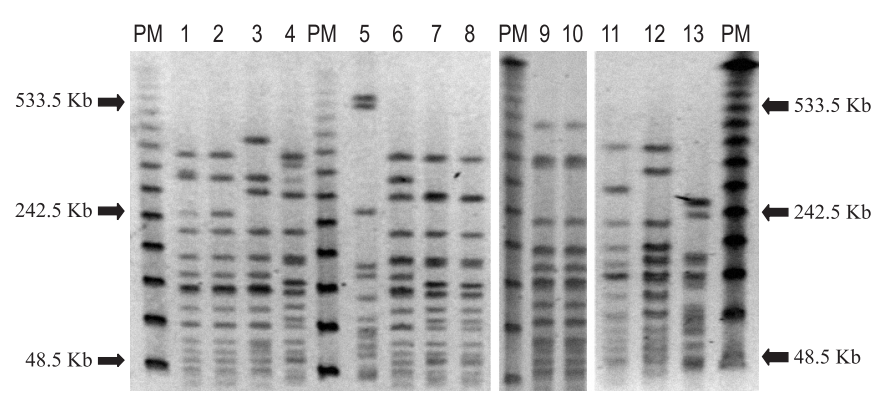

Figure 1. PFGE patterns of L. monocytogenes obtained with restriction enzyme A paI. PM = lambda ladder PFG marker (New England Biolabs). Isolates - 1: 2057/01; 2: 4231/00; 3: 16258/98; 4: 17898/98; 5: 7680/95; 6: 30464/01; 7: 1472/04; 8: 544/03; 9: 6280/04; 10: 5958/04; 11:432/05; 12: 1310/05; 13:22362/04. Strains number 9 and 10 were isolated from the same patient but from different sites of infection. 
Table 1. MICs $^{1}(\mu \mathrm{g} / \mathrm{mL})$ of antibiotics against Listeria monocytogenes isolated from clinical cases of listeriosis at the region covered by the Campinas Regional Laboratory of the Adolfo Lutz Institute, SP, Brazil, from January 1995 to May 2005.

\begin{tabular}{lccccc}
\hline & Ampicillin & Gentamicin & Trimethoprim & Sulfamethoxazole & Vancomycin \\
\hline IALC 7680/95 & 0.25 & 0.125 & 0.125 & 8 & 0.625 \\
IALC 16258/98 & 0.25 & 0.25 & 0.5 & 8 & 1 \\
IALC 17898/98 & 1 & 0.125 & 0.125 & 32 & 0.625 \\
IALC 4231/00 & 0.5 & 0.125 & 0.25 & 32 & 0.625 \\
IALC 22057/01 & 0.25 & 0.125 & 0.125 & 32 & 0.625 \\
IALC 30464/01 & 0.5 & 0.125 & 0.125 & 16 & 1 \\
IALC 544/03 & $\leq 0.25$ & 0.25 & 0.25 & 32 & 1 \\
IALC 1472/04 & 0.25 & 0.25 & 0.125 & 8 & 0.625 \\
IALC 5958/04 & 0.5 & 0.25 & 0.25 & 128 & 0.625 \\
IALC 6280/04 & 0.5 & 0.25 & 0.25 & 128 & 0.625 \\
IALC 22362/04 & 0.25 & 0.5 & 0.125 & 8 & 1 \\
IALC 432/05 & 0.5 & 0.25 & 0.125 & 4 & 1 \\
IALC 1310/05 & 1 & 0.25 & 0.125 & 8 & 0.625 \\
\hline
\end{tabular}

${ }^{1}$ MIC: Microdilution broth antimicrobial susceptibility test using cation adjusted Mueller-Hinton broth supplemented with lysed horse blood (according to NCCLS doc M7-A6, 2003, MIC Testing).

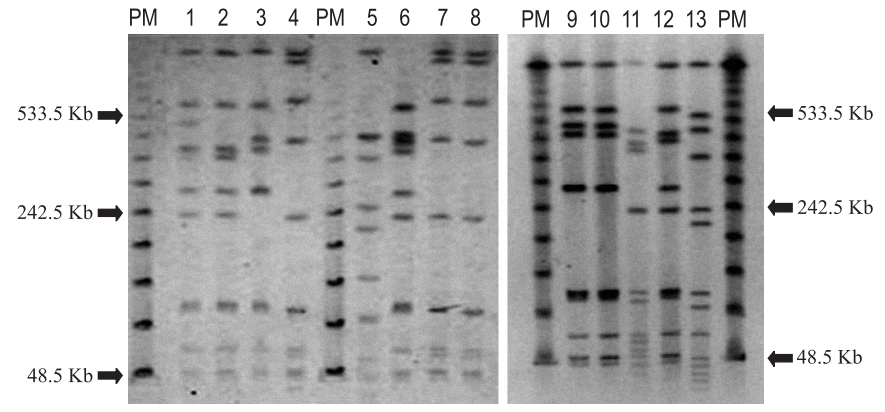

Figure 2. PFGE patterns of L. monocytogenes obtained with restriction enzyme AscI. PM = lambda ladder PFG marker (New England Biolabs). Isolates - 1: 2057/01; 2: 4231/00; 3: 16258/98; 4: 17898/98; 5: 7680/95; 6: 30464/01; 7: 1472/04; 8: 544/03; 9: 6280/04; 10:5958/04; 11:432/05; 12: 1310/05; 13:22362/04. Strains number 9 and 10 were isolated from the same patient but from different sites of infection.

\section{Serotyping}

The thirteen isolates belonged to three serotypes: ten strains (77\%) to serotype 4 b; two strains (15\%) to $1 / 2 \mathrm{a}$, and one strain (8\%) to $1 / 2$ b (Fig. 3).

\section{DISCUSSION}

Most industrialized countries have developed surveillance systems for listeriosis since 1987 (25), following outbreaks that demonstrated the importance of the foodborne transmission of the disease. Listeriosis has been mainly reported by those countries, with few or even no reports from Africa, Asia and South America. According to Rocourt et al. (25), whether this reflects different consumption patterns, dietary habits, different host susceptibility, or lack of testing facilities is not known. In order to help filling this gap, collecting some data from Brazil was one of the aims of this research.

The first antibiotic-resistant strain of $L$. monocytogenes was described in 1988 and, since then, other resistant strains have been detected in food and clinical isolates, including multidrugresistant strains (23). In this study, all the strains were susceptible to the antibiotics tested, except for sulfamethoxazole.

Until now, a combination of ampicillin and gentamicin has been successfully used against listeriosis; but, unfortunately, ampicillin and gentamicin-resistant clinical strains were already reported in different parts of the world (23). Studies previously conducted in Brazil have showed the presence of ampicillinresistant isolates $(3,4,10,16)$, but none of the results were tested or confirmed by the dilution methods. It is opportune to emphasize the importance of using a standardized method to test bacterial resistance to antibiotics. The disk diffusion method, although widely used, is not standardized nor recommended for fastidious bacteria like Listeria spp. (7). Thus, the Brazilian data on antibiotic resistance by $L$. monocytogenes should be interpreted with caution, especially with regard to those reports on ampicillin resistance, which have been worldly scattered.

The association of trimethoprim with a sulfonamide, such as sulfamethoxazole in co-trimoxazole, is considered a second choice therapy, especially for patients intolerant of penicillins. The most active agent in this combination seems to be 


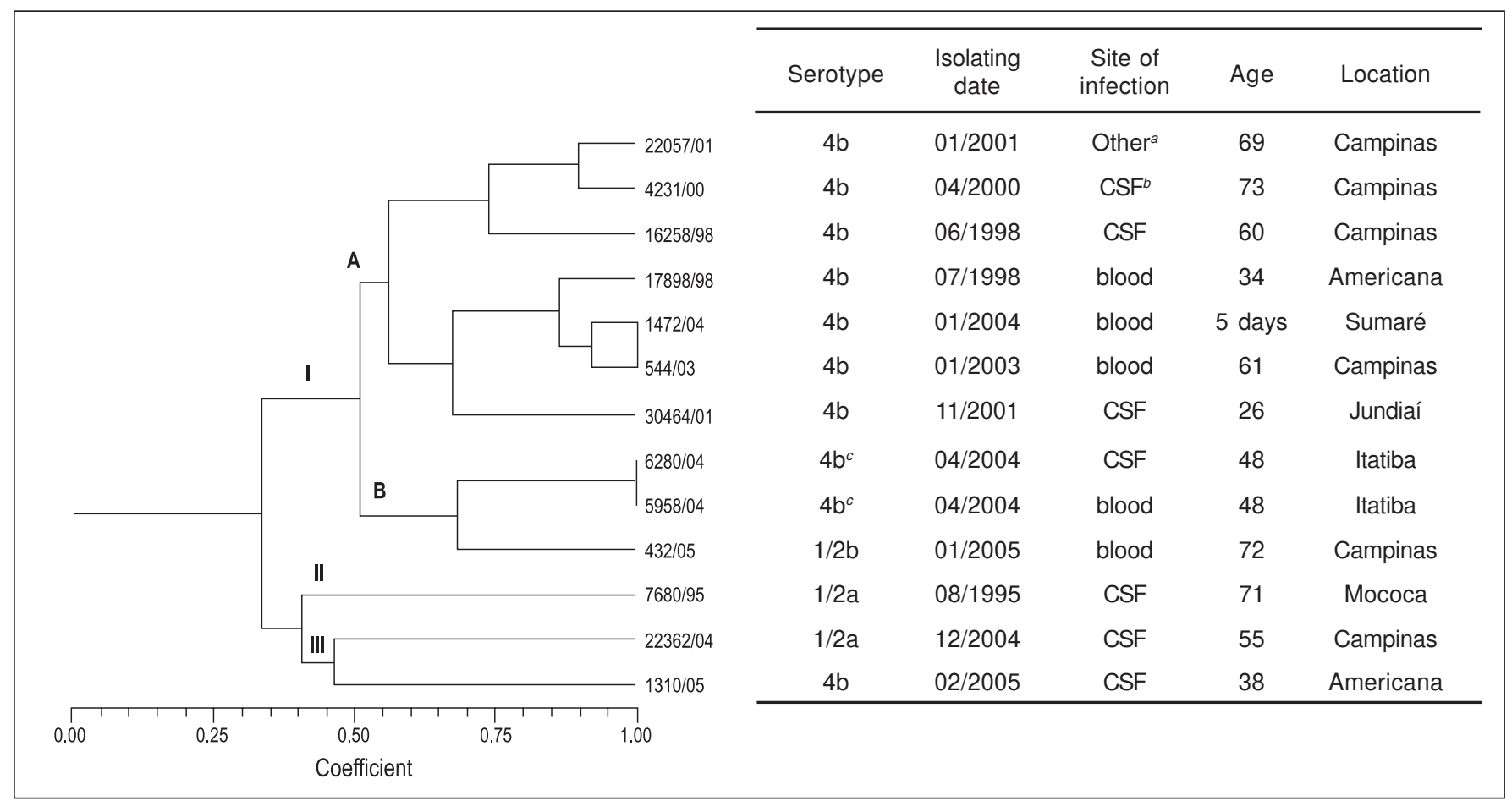

Figure 3. Dendrogram showing cluster analysis (unweighted pair group cluster method with arithmetic mean) of the 13 Listeria monocytogenes strains tested. The serotype, and other informations associated with each strain are also shown. ${ }^{a}$ Liquid of aorta prosthesis; ${ }^{b}$ Cerebrospinal fluid; ${ }^{c}$ Strains from the same patient.

trimethoprim, which is synergized by sulfamethoxazole. Charpentier et al. (5) described the first trimethoprim-resistant strain of L. monocytogenes and, according to these authors, the high level of resistance attained abolished the synergism usually observed between trimethoprim and sulfamethoxazole. In this study, these two drugs were tested individually and none of the strains showed resistance to trimethoprim. Additionally, there were increased values for sulfamethoxazole MICs (Table 1). Hofer et al. (14) mentioned the detection of three isolates resistant to trimethoprim-sulfamethoxazole in the Distrito Federal (Central region of Brazil), and Catão et al. (4) reported one isolate in Campina Grande (Northeastern region). However, those authors used the disk diffusion method employing the co-trimoxazole disk and could not estimate the resistance for each drug isolated. Nevertheless, these data were of particular concern since emergence and dissemination of antibiotic resistance in clinical isolates of $L$. monocytogenes could have important therapeutic consequences and should be monitored.

The three serotypes found in this research (4b, 1/2a and $1 /$ 2b) are in agreement with other data reported in Brazil (15), being the most prevalent in clinical cases worldwide (1).

Using the macrorestriction patterns obtained by PFGE with both restriction enzymes ApaI and AscI, the strains could be distributed in three groups (I to III; Figure 3). Group I can be clearly divided in two clusters (A and B) with all the strains from cluster A belonging to serotype $4 \mathrm{~b}$. The two strains in cluster B that could not be differentiated (6280/04 and 5958/04) belonged to the same patient. It is possible that a space-time relation between some of the strains from cluster A exists, since they were isolated from the same county in a period of 2.5 years.

Sauders et al. (26) stated that many reports claim that most listeriosis cases are sporadic, but based on their own data, they suggest that a considerable proportion of human listeriosis cases represent subtype clusters, some or all of which may represent common source outbreaks. Unfortunately, in the present study the sources of exposure were undetermined for all the 12 clinical cases evaluated and no epidemiological data were also available, for this reason no conclusive relationships could be determined. According to our results, the proportion of L. monocytogenes strains resistant to antibiotics in the region under study remains low. However, this current favorable situation of quasiuniform susceptibility to the antibiotics used in clinical practice may deteriorate under the selective pressure exerted by overuse of the drugs in the country.

In Brazil, few clinical cases of listeriosis have been reported and none of them had their source of infection established. In addition, once listeriosis is not a disease under compulsory 
notification, there are no registers identifying L. monocytogenes in clinical samples in many regions of the country. Whether this reflects the absence of cases or a lack of testing facilities is unknown. Furthermore, even when an early diagnosis would be possible, the long time for the onset of the clinical symptoms difficult the identification of the source of infection. Subtyping methods will only provide their full public health benefit if food histories were routinely obtained for all listeriosis patients to provide an epidemiological support for putative single genotype clusters.

Finally, it is known that the cases documented here may not represent the true incidence in the community, especially with regard to perinatal infection, once many laboratories of the region covered by this study do not often send the isolates for further characterization by the Regional Lab. Sometimes, such labs are not capacitated to make a correctly identification of this bacterium. To improve such scenario, public health laboratories in Brazil should become able to isolate and identify L. monocytogenes. Also, a laboratory-based surveillance system and a nationwide genotyping system should be implemented to detect and investigate sporadic cases or outbreaks of human listeriosis and their source of infection. Only by developing such capabilities, the true incidence of human listeriosis in Brazil could be established.

\section{RESUMO}

\section{Caracterização feno e genotípica de cepas de Listeria monocytogenes isoladas de casos clínicos na região sudoeste do Estado de São Paulo, Brasil}

No Brasil, dados sobre a ocorrência de surtos ou casos esporádicos de listeriose são raros, assim como estudos que tratem da caracterização de cepas de L. monocytogenes isoladas destes episódios. Desta forma, o presente estudo teve por objetivo avaliar feno e genotipicamente 13 cepas de Listeria monocytogenes isoladas de 12 casos clínicos de listeriose ocorridos em 6 municípios da região sudoeste do Estado de São Paulo, Brasil, no período de janeiro de 1995 a maio de 2005. As cepas foram submetidas ao teste de sensibilidade a cinco antimicrobianos (ampicilina, gentamicina, trimetoprim, sulfametoxazol e vancomicina) pelo método de microdiluição em caldo; à sorotipagem (Denka Seiken, Japão) e à determinação do perfil de macro-restrição por eletroforese em campo pulsado (PFGE, Pulsenet, CDC, USA, 2001). Nenhuma das cepas foi resistente aos antimicrobianos testados; entretanto, sete tiveram valores da CIM aumentados para o sulfametoxazol. Dez cepas pertenciam ao sorotipo $4 \mathrm{~b}$, duas ao sorotipo $1 / 2 \mathrm{a}$ e apenas uma ao sorotipo $1 / 2 \mathrm{~b}$. Com o emprego da técnica de PFGE e as enzimas ApaI e AscI as cepas foram separadas em três grupos diferentes, de acordo com seus perfis moleculares. É interessante destacar que cepas não relacionadas (temporal ou espacialmente) apresentaram perfis moleculares semelhantes indicando uma possível relação clonal entre elas.

Palavras-chave: Listeria monocytogenes; sorotipagem; resistência a antimicrobianos; caracterização genotípica; listeriose.

\section{REFERENCES}

1. Armand-Lefèvre, L.; Ewill, G.; Alain, S. (2003). La listeriosis. Epidemiología, fisiopatología, diagnóstico clínico, biodiagnóstico. Acta Bioquim. Clin. Latinoamer., 37(1), 71-79.

2. Aureli, P.; Fiorucci, G.C.; Caroli, D.; Marchiaro, G.; Novara, O.; Leone, L.; Salmaso, S. (2000). An outbreak of febrile gastroenteritis associated with corn contaminated by Listeria monocytogenes. $N$. Engl. J. Med., 342, 1236-1241.

3. Campos, E.P.; Carvalho, V.O.; Kushnaroff, T.M.; Galvão, P.A.A.; Campos, C.E.O.P. (1997). Listerial meningoencephalitis: AIDS and non AIDS patients. F. méd. (BR), 114(1), 39-42.

4. Catão, R.M.R.; Vigolvino, W.A.; Andrade, W.T.; Hofer, E. (2003). Meningite por Listeria monocytogenes em Campina Grande - Paraíba, Brasil: relato de um caso. Rev. Bras. Anal. Clin., 35(2), 81-83.

5. Charpentier, E.; Gerbaud, G.; Jacquet, C.; Rocourt, J.; Courvalin, P. (1995). Incidence of antibiotic resistance in Listeria species. J. Infect. Dis., 172, 277-281.

6. Charpentier, E.; Courvalin, P. (1999). Minireview: Antibiotic resistance in Listeria spp. Antimicrob. Agents Chemoter., 43(9), 2103-2108.

7. Clinical and Laboratory Standards Institute/NCCLS. Performance Standards for Antimicrobial Susceptibility Testing; Fifteenth Informational Supplement. (2005). CLSI/NCCLS document M100S15. CLSI, Wayne, PA., USA.

8. Dalton, C.B.; Constance, C.A.; Sobel, J.; Hayes, P. S.; Bibb, W.F.; Graves, L.M.; Swaminathan, B.; Proctor, M.E.; Griffin, P.M. (1997). An outbreak of gastroenteritis and fever due to Listeria monocytogenes in milk. N. Engl. J. Med., 336(2), 100-105.

9. Doyle, M.E. (2001). Virulence characteristics of Listeria monocytogenes. FRI Briefings, University of Wisconsin-Madison, Food Research Institute, Madison, WI, 13p.

10. Esper, M.R.N.R.; Pessoa, G.V.A.; Hofer, E.; Lee, I.M.L.; Melles, C.E.A.; Sakata, E.E.; Calzada, C.T. (1978). Meningite por Listeria monocytogenes em São Paulo, Brasil. Rev. Inst. Adolfo Lutz, 38(1), $37-41$.

11. Graves, L.M.; Swaminathan, B. (2001). Pulsenet standardized protocol for subtyping Listeria monocytogenes by macrorestriction and pulsedfield gel electrophoresis. Int. J. Food Microbiol., 65, 55-62.

12. Hofer, C.B.; Melles, C.E.; Hofer, E. (1999). Listeria monocytogenes in renal transplant recipients. Rev. Inst. Med. Trop. S. Paulo, 41(6), 375-377.

13. Hofer, E.; Oliveira, L.M.A. (1988). Sensibilidade antimicrobiana em amostras de Listeria isoladas de diferentes fontes e regiões do Brasil. Rev. Microbiol., 19(2), 109-112.

14. Hofer, E.; Nascimento, R.S.; Oliveira, M.A. (1998). Meningite por L. monocytogenes. Relato de casos em pacientes do Distrito Federal Rev. Soc. Bras. Med. Trop., 31(12), 173-177.

15. Hofer, E.; Ribeiro, R.; Feitosa, D.P. (2000). Species and serovars of the genus Listeria isolated from different sources in Brazil from 1971 to 1997. Mem. Inst. Oswaldo Cruz, 95(5), 615-620.

16. Landgraf, I.M.; Kobata, A.M.M.; Jakabi, M.; Kirschbaum, C.R.A.; Marchi, C.R. (1999). Surto de meningite neonatal por Listeria monocytogenes. Rev. Inst. Adolfo Lutz, 58(1), 63-67.

17. Leal, N.C.; Hofer, E.; Costa, M.F.; Sá, A.T. (1983). Isolamento de L. monocytogenes de líquido céfalorraquidiano em Recife, PE. Rev Microbiol., 14(4), 290-291. 
18. Lemes-Marques, E.G.; Yano, T. (2004). Influence of environmental conditions on the expression of virulence factors by Listeria monocytogenes and their use in species identification. FEMS Microbiol. Lett., 239, 63-70.

19. Loguercio, A.P.; Silva, W.P.; Aleixo, J.A.G.; Costa, M.M.; Vargas, A.C. (2001). Listeria monocytogenes: um importante patógeno de origem alimentar. Hig. Alim., 15(80/81), 39-48.

20. National Committee for Clinical Laboratory Standards: Methods for dilution antimicrobial susceptibility tests for bacteria that grow aerobically; approved standard - sixth edition. (2003). NCCLS document M7-A6. NCCLS, Wayne, PA., USA.

21. Nojimoto, I.T.I.; Centeno, A.J.; Yanaguita, R.M.; Watanabe, K.; Kakumoto, M.; Machado, M.R. (1994). Susceptibilidade aos antimicrobianos de Listeria spp. isoladas de pacientes com aborto repetitivo. Rev. Bras. Anal. Clin., 26(3), 71-74.

22. Pereira, M.L.; Buchrieser, C.; Brosch, R.; Catimel, B.; Rocourt, J.; Hofer, E. (1994). Characterization of brazilian Listeria monocytogenes strains using DNA macrorestriction patterns. Rev. Microbiol., 25(3), 144-148.

23. Poros-Gluchowska, J.; Markiewicz, Z. (2003). Antimicrobial resistance of Listeria monocytogenes. Acta Microbiol. Pol., 52(2), 113-129.

24. Rocourt, J.; Schrettenbrunner, A.; Seeliger, H.P.R. (1983). Différenciation biochimique des groupes génomiques de $L$. monocytogenes (sensu lato). Ann. Microbiol. (Inst. Pasteur), 134 A, 65-71.

25. Rocourt, J.; Jacquet, C.; Reilly, A. (2000). Epidemiology of human listeriosis and seafoods. Int. J. Food Microbiol., 62, 197-209.

26. Sauders, B.D.; Fortes, E.D.; Morse, D.L.; Dumas, N.; Kiehlbauch, J.A.; Schukken, Y.; Hibbs, J.R.; Wiedmann, M. (2003). Molecular subtyping to detect human listeriosis clusters. Emerg. Inf. Dis., 9(6), 672-680.

27. Seeliger, H.P.R.; Höhne, K. (1979). Serotyping of Listeria monocytogenes and related species. In: Bergan, T.; Norris, J.R. (eds). Methods in Microbiology. Academic Press, London, p.31-49.

28. Siegman-Igra, Y.; Levin, R.; Weinberger, M.; Golan, Y.; Schwartz, D.; Samra, Z.; Konigsberger, H.; Yinnon, A.; Rahav, G.; Keller, N.; Bisharat, N.; Karpuch H.; Finkelstein, R.; Alkan, M.; Landau, Z.; Novikov, J.; Hassin, D.; Rudnicki, C.; Kitzes, R.; Ovadia, S.; Shimoni, Z.; Lang, R.; Shohat, T. (2002). Listeria monocytogenes infection in Israel and review of cases worldwide. Emerg. Infect. Dis., 8, 305-310.

29. Sneath, P.H.A.; Sokal, R.R. (1973). Numerical taxonomy. Freeman, San Francisco, LA, USA, 573 p.

30. Tenover, F.C.; Arbeit, R.D.; Goering, R.V.; Mickelsen, P.A.; Murray, B.E.; Persing, D.H.; Swaminathan, B. (1995). Interpreting chromosomal DNA restriction patterns produced by Pulsed-field gel electrophoresis: criteria for bacterial strain typing. J. Clin. Microbiol., $33,2233-2239$. 